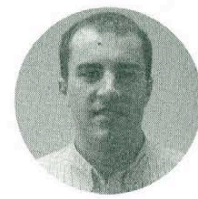

QUINTIN BARNES

is a member of the Arts \& Sciences Class of 2009 and graduated with an honors degree in Philosophy and a degree in Political Science. He is an Alpha Sigma Nu member and a Golden Key scholar and was president of the volunteer organization Hoops for Hope. “Today's Russian Intelligentsia: A New Role in the Post-Soviet Political Order" is adapted from Professor Paul Christensen's course, Post-Soviet Politics.

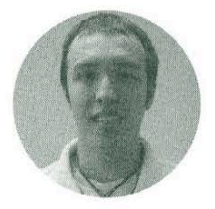

\title{
CHRISTOPHER BRUNNER
}

hails from Oak Park, Illinois. He is a junior in the Lynch School of Education where he is currently studying Mathematics and Secondary Education. His research interests include social and cultural issues affecting youth development, especially in education. He has recently completed a project with the Community Research Program studying the effect of socioeconomic stress on parental involvement in high schools and will be continuing to do reseach with LSOE this fall.

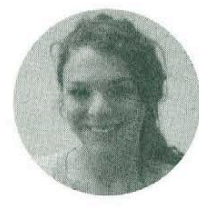

\section{ALYSSA HUGHES}

originally from Kea'au, Hawaii, is a junior in the College of Arts \& Sciences majoring in History and completing a minor in Secondary Education. She wrote this paper for Professor Dana Sajdi's course "The Study and Writing of History: Arabian Nights." She currently volunteers at the Haley House Soup Kitchen with the 4 Boston program. She would like to thank Professor Sajdi for all her guidance.

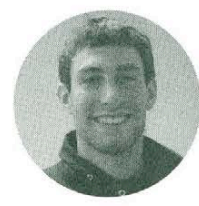

\section{NATHAN KEEGAN}

graduated in May 2009 with a degree in Linguistics and Latin American Studies. His interest in popular music studies grew from his experiences as songwriter, producer, and multi-instrumentalist in the awardwinning BC hip-hop group The Keegan Brothers Trio. He is currently serving as a WorldTeach Volunteer Fellow in Kosrae, Micronesia, where he teaches mathematics. 


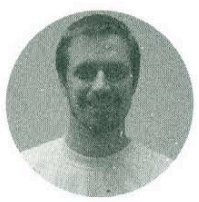

CHRISTOPHER MAROSHEGYI

graduated from BC in May 2009 with a B.A. in International Studies, concentrating in Political Science, and a minor in Islamic Civilizations and Societies and Economics. Christopher drew his inspiration for this piece from his parents, whose stories as immigrants from Hungary as a result of the Cold War implanted a sense of purpose to study development and migration. This article has been expanded in a recently completed thesis, titled Exporting Citizens: The Power Politics and Economics Behind Moroccan Emigration Policy. Christopher is currently researching economic development in Hungary on a Fulbright Scholarship.

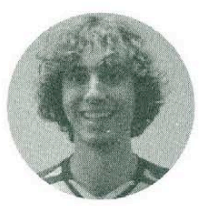

\section{MATTHEW MORRIS}

like his mother and Doug Flutie, is a native of Natick, MA and a graduate of Boston College. A Communications major and History minor, his past research has concerned doctor/patient relationships, new media, and European nationalisms. He was the President of College Bowl for two years and once hit five half-court shots in a row in high school. He dreams one day of employment.

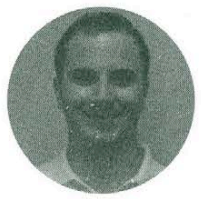

\section{CHRISTOPHER SCULLIN}

studies Political Science and Philosophy, and both looks forward to and dreads graduating from the Boston College Honors Program in May 2010. Chris spends most of his time missing the weather in Los Angeles, his native locale, and attempting to be as awesomely multifaceted as possible. He is also most interested in the crossroads of his two subjects of study, how individual needs do battle with those of society. This paper was written during a junior-year semester abroad at King's College, London, for the course Global Conflict in the Contemporary World. 